\title{
ANEURYSMAL BONE CYST OF A VERTEBRAL BODY WITH ACUTE PARAPLEGIA
}

\author{
By I. Shacked, M.D., R. Tadmor, M.D., G. Wolpin, M.D., A. Ohry, M.D. \\ The Department of Neurosurgery, Department of Radiology, and the Sir Ludwig \\ Guttmann Spinal Cord Injury Center, Chaim Sheba Medical Center, Tel-Hashomer \\ and the Sackler School of Medicine, Tel-Aviv University, Israel
}

\begin{abstract}
Aneurysmal bone cyst of a vertebral body presenting with acute paraplegia is reported. Complete recovery followed immediately after surgery.
\end{abstract}

Key Words: Aneurysmal bone cyst; Vertebra; Paraplegia.

\section{Introduction}

ANEURYSMAL bone cyst is a rare benign lesion of young patients, usually located in metaphyses of long bones and in the posterior elements of the vertebral column (Barnes, I956; Donaldson, I962; Hay et al., I978; Koskinen et al., I976; Verbiest, 1965). It was first described as a distinct clinical and pathological entity by Jaffe and Lichtenstein in 1942. Extension of this process may cause extradural compression of the spinal cord and nerve roots, resulting in neurological deficits such as radiculitis, paraparesis and sometimes paraplegia (Dabska et al., 1969; Lichtenstein, 1958; McCarty et al., I96I; McArthur et al., I966; Tillman et al., 1968).

The case described below illustrates an unusual clinical presentation of aneurysmal bone cyst of the vertebral body, which resulted in an expanding lesion with paraplegia.

\section{Case report}

A 26-year-old male was hospitalised complaining of mid-dorsal back pain, tingling and numbness of the lower limbs with difficulties in urination. Physical examination revealed complete paralysis of the lower extremities with a sensory level at D6. The urinary bladder was markedly enlarged due to urine retention, and the sphincter ani was atonic. The general examination was unremarkable. X-ray studies of the spine showed erosion of the left pedicle at D6. Hypocycloidal tomography demonstrated an expanding destructive lesion within the vertebral body at the same level (Fig. Ia, b). Due to rapid progression of the clinical course, myelography was performed, this disclosed an extradural complete block to the oil column at D6-D7 (Fig. 2). Operation was performed immediately. Reflection of the soft tissues and paravertebral muscles revealed destruction of the spinous process and part of the lamina on the left side at D6. Laminectomy at D6 and D7 was performed. The spinal cord was found to be enveloped extradurally by a spongy vascular tissue attached to the centre of the body of D6. After curettage and removal of the entire tumorous tissue, a cavity $2 \times 2 \mathrm{~cm}$ remained within that vertebral body. Histological examination revealed a highly vascularised tumour, consisting of honeycombed blood containing spaces lined by endothelium and with multiple giant cells and haemosiderin in the surrounding tissue. The appearance was that of an aneurysmal bone cyst. 

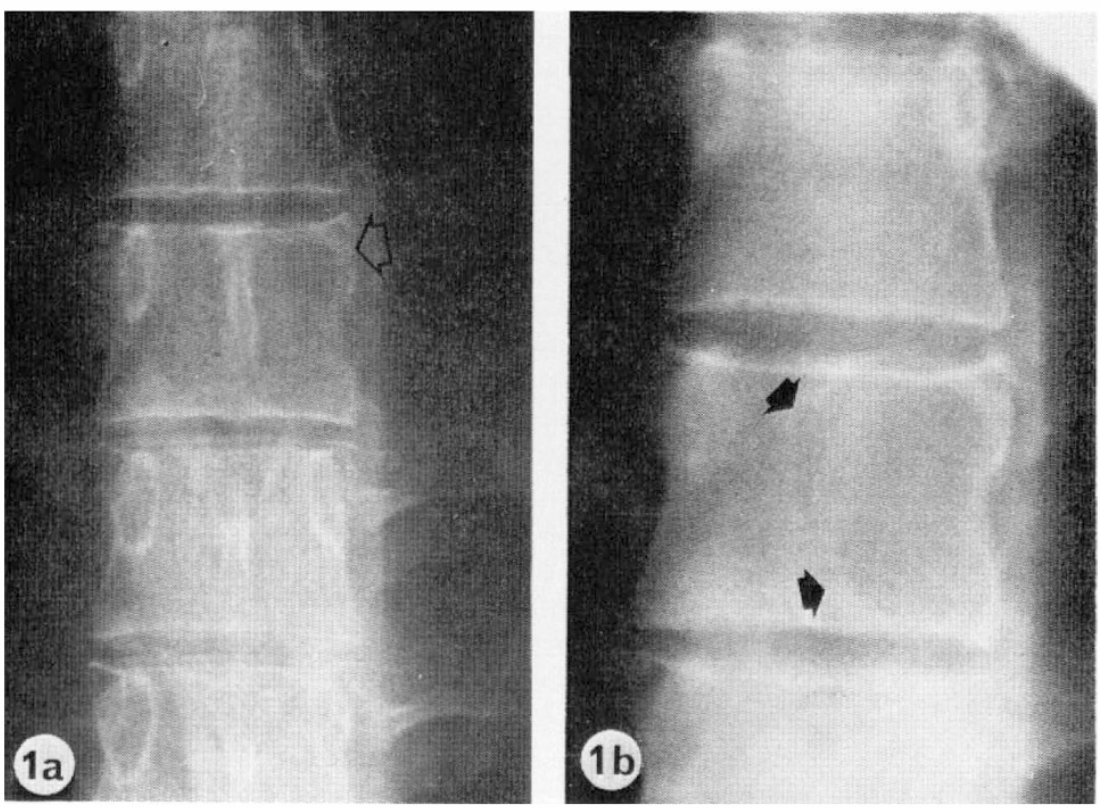

FIG. I

(a) X-ray of the thoracic spine. A.P. view showing the left pedicle of D6 to be absent (arrow). (b) Hypocycloidal tomography demonstrating the expansive lytic process of the vertebral body (arrows).
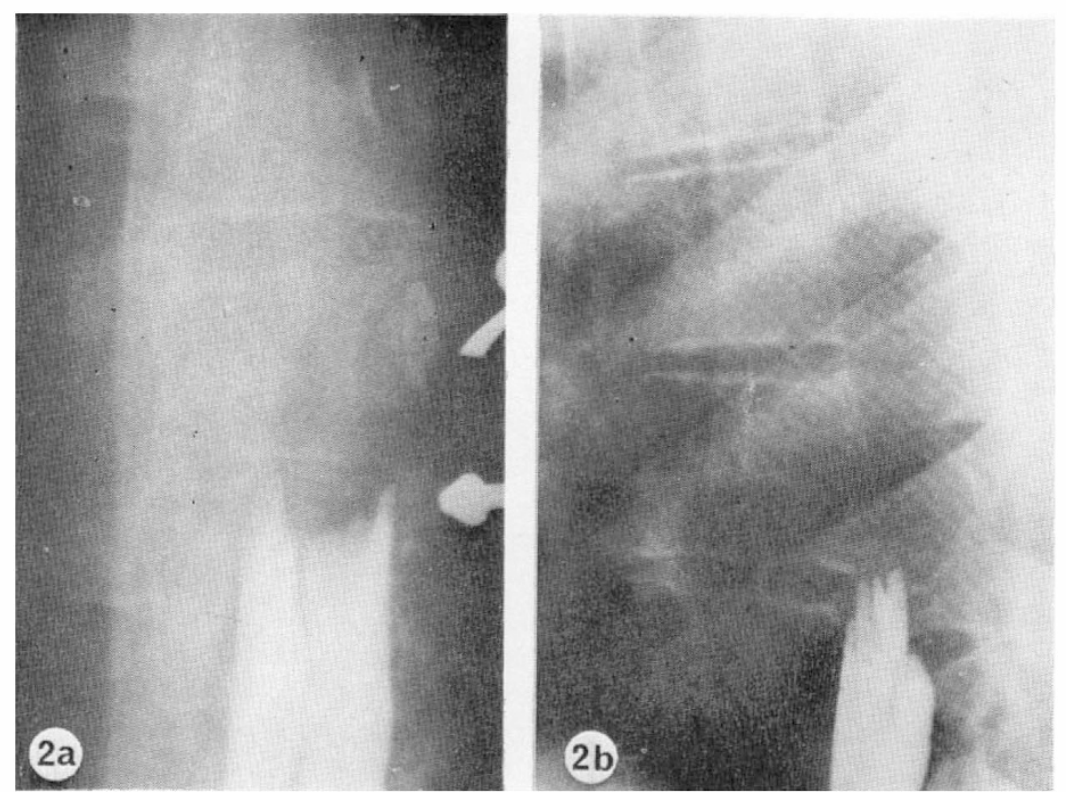

FIG. 2

$(a, b)$ Myelography: A complete extradural block of the oily column is seen at D6-D7 on A.P. and lateral views. 
The post-operative course was uneventful with gradual recovery from almost all neurological deficits. Within a period of 3 months muscle power and sensory loss returned to normal and the patient regained control of his sphincters. Four years after the operation he was asymptomatic and fully recovered neurologically.

\section{Discussion}

Aneurysmal bone cyst is considered a benign tumour. It usually occurs in the young, the majority of patients being in the second or third decade of life. This tumour is usually located in the metaphyses of long bones and in the posterior elements of the vertebral column, especially in the lumbar region. Occasionally it is also found in the vertebral body and in other bones such as the clavicle, olecranon and in the skull (Parrish et al., 1967; Subramanian and Mathias, 1969; Koskinen et al., 1976; Hay et al., 1978).

The clinical features of aneurysmal bone cyst of the spine are pain and stiffness of the affected region. Additional symptoms may appear as the lesion expands and pressure is exerted on the spinal cord and nerve roots. The symptoms of a compressive lesion of the spinal cord are a result of the lesion's size and the rate of growth. A slowly growing lesion causes spasticity, weakness, faulty gait and sensory loss. The neurologic manifestations may appear 3-6 months following the onset of the initially compressive lesion and occasionally even after several years. A rapidly advancing lesion, causes sudden paraplegia with urine retention areflexia (Bekler et al., 1956; Taylor, 1956; Fisher, 1966; Dabska and Buraczewsky, I969).

It is known that acute spinal cord compression paralysis may appear in patients suffering from a collapsed vertebra, protruded intervertebral disc, spinal epidural abscess, neoplasm or haemorrhage, either traumatic or spontaneous.

The paralysis may be the result of direct mechanical pressure on the spinal cord and nerve roots or due to anoxia of the cord secondary to obstruction of the supplying blood vessels leading to necrosis (Bekler et al., 1957; McArthur and Fisher, I966; Dabska and Buraczewsky, 1969; Tarlov, 1974; McAllister et al., 1975).

According to experimental works cited by Tarlov (1974) there is evidence that mechanical factors are the main cause of acute paralysis. However, there is a great capacity for recovery of spinal cord functions, following removal of the compressive cause.

Tarlov (1974) and Gelfan et al. (1967) postulated that although the compressed segment of cord is ischaemic, diffusion of oxygen to that area persists from the adjacent non ischaemic tissues. Therefore delayed diagnosis and surgical intervention may lead to an irreversible cord damage with permanent neurological deficits.

In the case presented, we assume that the sudden onset of paraplegia occurred as a result of expansion of the tumour into the extradural space due to spontaneous haemorrhage inside the mass, as shown at surgery. Recovery may occur if urgent laminectomy with decompression of the affected segment of the spinal cord are performed. There is much controversy about the role of irradiation in the management and treatment of aneurysmal bone cyst of the spine. However, most of the authors recommend surgical excision only. According to Tillman et al. (I968) even incomplete removal usually gives a good result. Radiation therapy on the contrary did not appear to be effective. It may introduce the hazard of post radiation sarcoma (Tillman et al., I968 and Dabska et al., I969). 


\section{SUMMARY}

A 26-year-old male patient suffering from an aneurysmal bone cyst of a vertebra. Acute paraplegia was the presenting feature and complete recovery followed laminectomy and tumour excision.

The importance of an early diagnosis and immediate surgical intervention to prevent permanent neurological damage is emphasised.

\section{RÉSUMÉ}

Un Kyste aneurysmal d'une vertèbre chez un malade de 26 ans est presenté. Une paraplégie aigue en était le symptome dominant et elle a règressée complètement après l'excision de la tumeur. Le diagnostic précoce et l'intervention immédiate sont capitals de façon a éviter les séquells neurologique permanents.

\section{ZUSAMMENFASSUNG}

Es wird über einen Fall von einer aneurysmalen Knochenzyste des Wirbels in einem 26 jährigen Patient berichtet. Akute Paraplegie war das Hauptsymptom und volle Heilung folgte nach Laminectomy und Excision des Tumors. Es wird nachdrücklich darauf hingewiesen daß die Frühdiagnose und anschließende chirurgische Intervention einen permanenten neurologischen Schaden verhindern kann.

\section{REFERENCES}

Barnes, R. (1956). Aneurysmal bone cyst. f. Bone ft. Surg., 38B: 301 .

Besse, B. E. Jr., Dahlin, D. C., Pugh, D. G. and Ghormley, R. K. (I956). Aneurysmal bone cysts; additional considerations. Clin. Orthop., 7, 93-I02.

Bekler, J. W., Helman, C. H. and Campbell, J. A. (1957). Aneurysmal bone cyst of spine. f. Amer. Med. Assoc., 165, 914-918.

Dabska, M., BuraczewsKy, J. (I969). Aneurysmal bone cyst. Cancer, 23, 37I-389.

Donaldson, W. F. (1962). Aneurysmal bone cyst., f. Bone ft. Surg., 44A, 25-40.

Gelfan, S., TARLov, I. M. (1956). Physiology of the spinal cord, nerve root and peripheral nerve compression. Amer. F. Physiol., 185, 227-229.

Hay, M. C., Paterson, D. and Taylor, T. K. F. (I978). Aneurysmal bone cysts of the spine. F. Bone ft. Surg., 60B, 406-4II.

JAFFe, H. L., LichtensteIn, L. (I942). Solitary unicameral bone cyst with emphasis on the roentgen picture: Pathologic appearance and the pathogenesis. Arch. Surg., 44, 1004-I025.

Koskinen, E. V. S., Visuri, I. I., Holmstrom, R. and Roukkula, M.A. (1976). Aneurysmal bone cyst. Evaluation of resection and currettage in 20 cases. Clin. Orth. Rel. Res., I18, I37-1 43 .

Lichtenstein, L. (1958). Aneurysmal bone cyst. Observation in fifty cases. F. Bone ft. Surg., 39A, 873-882.

MacCarty, C. S., Dahlin, D. C., Doyle, J. B., Lipscombe, P. R. and Pugh, D. J. (I96i). Aneurysmal bone cysts of the neural axis. F. Neurosurg., 18, 67I-677.

McAllister, V. L., Kendall, B. E. and Bull, J. W. D. (I975). Symptomatic vertebral hemangiomes. Brain, 98, $7 \mathrm{I}-80$.

MCARthUR, R. A., Fisher, R. G. (1966). Aneurysmal bone cyst involving the vertebral column. A case report. f. Neurosurg., 24, 772-776.

PARrish, F. F., PEREY, J. K. (1967). Surgical management of aneurysmal bone cysts of the vertebral column. F. Bone ft. Surg., 49A, I 597-1604.

Praksh, B., Banerja, A. K. and Tandon, P. N. (I973). Aneurysmal bone cyst of the spine. F. Neurol. Neurosurg. Psych., 36, I I 2-I I 7.

Subramanian, C. S. V., Mathias, P. F. (1969). Aneurysmal bone cyst. F. Bone ft. Surg., 44B, 93-IOI. 
Tarlov, I. M. (1974). Acute Spinal cord compression paralysis. F. Neurosurg., 36, IO-20.

TAYLOR, F. W. (I956). Aneurysmal bone cyst. F. Bone ft. Surg., 38B, 293-300.

Tillman, B. P., Dahlin, D. C., Lipscomb, P. R. and Steward, J. R. (I968). Aneurysmal bone cysts. An analysis of 95 cases. Mayo Clin. Proc., 43, 478-495.

Verbiest, H. (I965). Giant cell tumour and aneurysmal bone cysts of the spine. F. Bone ft Surg., 47B, 699-713. 